\title{
Signed, sealed and delivered: "big tobacco" in Hollywood, 1927-1951
}

\author{
K L Lum, ${ }^{1}$ J R Polansky, ${ }^{2}$ R K Jackler, ${ }^{3}$ S A Glantz ${ }^{4}$
}

${ }^{1}$ Center for Tobacco Control Research and Education, University of California, San Francisco, California, USA;

${ }^{2}$ Onbeyond LLC, Fairfax, California, USA; ${ }^{3}$ Department of Otolaryngology - Head \& Neck Surgery, Stanford University School of Medicine, Stanford, California, USA; ${ }^{4}$ Center for Tobacco Control Research and Education and Department of Medicine, University of California, San Francisco, California, USA

Correspondence to:

S A Glantz, Center for Tobacco Control Research and Education and Department of Medicine,

University of California, 530 Parnassus Ave \#366, San Francisco, California, 941431390, USA; glantz@medicine. ucsf.edu

Received 14 March 2008 Accepted 18 July 2008

\begin{abstract}
Objective: Smoking in movies is associated with adolescent and young adult smoking initiation. Public health efforts to eliminate smoking from films accessible to youth have been countered by defenders of the status quo, who associate tobacco imagery in "classic" movies with artistry and nostalgia. The present work explores the mutually beneficial commercial collaborations between the tobacco companies and major motion picture studios from the late 1920s through the 1940s.
\end{abstract}

Methods: Cigarette endorsement contracts with Hollywood stars and movie studios were obtained from internal tobacco industry documents at the University of California, San Francisco (UCSF) Legacy Tobacco Documents Library and the Jackler advertising collection at Stanford.

Results: Cigarette advertising campaigns that included Hollywood endorsements appeared from 1927 to 1951, with major activity in 1931-2 and 1937-8 for American Tobacco Company's Lucky Strike, and in the late 1940s for Liggett \& Myers' Chesterfield. Endorsement contracts and communication between American Tobacco and movie stars and studios explicitly reveal the crosspromotional value of the campaigns. American Tobacco paid movie stars who endorsed Lucky Strike cigarettes US\$218 750 in 1937-8 (equivalent to US\$3.2 million in 2008) for their testimonials.

Conclusions: Hollywood endorsements in cigarette advertising afforded motion picture studios nationwide publicity supported by the tobacco industry's multimillion US dollar advertising budgets. Cross-promotion was the incentive that led to a synergistic relationship between the US tobacco and motion picture industries, whose artefacts, including "classic" films with smoking and glamorous publicity images with cigarettes, continue to perpetuate public tolerance of onscreen smoking. Marketbased disincentives within the film industry may be a solution to decouple the historical association between Hollywood films and cigarettes.

Smoking in movies is a major reason for adolescent $^{1-4}$ and young adult ${ }^{5}$ smoking initiation. Because there is a dose-response relationship in the effect of smoking in movies on adolescent smoking, public health authorities have urged that smoking be removed from films rated for youth audiences by rating future movies with smoking " $\mathrm{R}$ " in the USA (or "18" in the UK or "18A" in Canada). Such a change would reduce adolescent exposure to smoking by about $60 \%$ and prevent an estimated 200000 youth from starting to smoke in the US alone. ${ }^{67}$

Paid product placement of tobacco products in movies between $1970^{8}$ and the mid-1990s ${ }^{9}$ is well documented. Nevertheless, when public health experts call for the film industry to eliminate smoking from future movies accessible to youth, ${ }^{6}$ defenders of the status quo argue that smoking has been prominent on screen since the silent film era ${ }^{10}$ and that tobacco imagery is integral to the artistry of American film, citing "classic" smoking scenes in such films as Casablanca (1942) and Now, Voyager (1942). ${ }^{11-13}$ This argument does not consider the possible effects of commercial relationships between the motion picture and tobacco industries during this period. This paper examines the relationship between the motion picture and tobacco industries during the "studio system" era, when major film companies held actors to multiyear contracts and controlled most first-run movie theatres.

\section{METHODS}

Internal tobacco industry documents at the University of California, San Francisco (UCSF) Legacy Tobacco Documents Library (http://www. legacy.library.ucsf.edu) were obtained through keyword searches, including "movie endorsement", "agreement", "testimonial", "Hollywood" and "screen/movie star" and major studio names (e.g., "Paramount", "Warner Bros") between November 2007 and February 2008. The snowball method and surrounding Bates number searches were used to investigate the evolution of certain endorsement contracts or advertising campaigns. Endorsement contracts were also related to additional cigarette advertisements found from a review of the Robert Jackler collection of tobacco advertisements (http://tobacco.stanford.edu) in January and July 2008. Online archives of the Los Angeles Times and New York Times were searched using such terms as "testimonial", "endorsement" and "tobacco advertising". Relevant advertising budgets were obtained from the US Census Bureau's Statistical Abstract and the marketing journal Printer's Ink. In total, 246 archival documents were ultimately analysed. Movie, studio and actor details were obtained from the Internet Movie Database (http://www.imdbpro.com). US dollar values were adjusted for inflation to 2008 equivalents using the average Consumer Price Index for the relevant year.

Keyword searches found that tobacco company print and radio endorsement contracts with motion picture figures, and related studio correspondence were concentrated between 1927-1951; from the advent of "talking" motion pictures to the rise of television. The number of Hollywood endorsements in print adverts and radio broadcasts between 1927-1951 was determined by reviewing cigarette advertisements and radio program 
transcripts in the Legacy Tobacco Documents Library and the Jackler collection. Endorsements were defined by endorser, advertising copy, movie tie-in and accompanying contract agreement, and counted in the year of first appearance. The extent to which major studios engaged in tobacco crosspromotion was determined by the number of times a specific studio was mentioned in a cigarette print advert or Hollywood guest star appearance on a tobacco-sponsored radio program. Monetary considerations made to Hollywood stars for their testimonials were taken from endorsement agreements and converted into 2008 US dollar equivalents.

\section{RESULTS}

Cross-promotion arrangements (then termed "tie-ins", "tieups" or "exploitation") generating publicity for tobacco companies and studios originated from cigarette advertising featuring testimonials from stage celebrities such as Florenz Ziegfield and Helen Hayes. ${ }^{11}$ Cigarette advertising campaigns exploiting Hollywood celebrity while promoting films from the major studios appeared from 1927 to 1951, but creation of new adverts peaked in three major campaigns: 1931-2 and 1937-8 for American Tobacco's Lucky Strike and in the late 1940s for Liggett \& Myers' Chesterfield (fig 1).

\section{Tobacco companies give Hollywood national advertising}

Advertising-driven competition among Lucky Strike, Chesterfield and Camel cigarette brands made the tobacco industry among the biggest advertisers in the USA. In 1929, American Tobacco spent US\$6.5 million (US\$80 million in 2008) on print and radio advertising, more than three times the US\$1.9 million (equivalent to US\$23 million in 2008) RJ Reynolds spent on Camels, the leading brand. In the worsening Great Depression of 1930, American Tobacco's Lucky Strike boosted its print and radio advertising budget by 53\% (US $\$ 126$ million in 2008), gaining market share from Camel and Chesterfield to win first place. ${ }^{14}$

By contrast, the motion picture industry relied on modest "co-op" spending (budgeted promotional campaigns with dual benefit to the vendor and retailer) for theatre listings, trailers of coming attractions, lobby posters and word of mouth. ${ }^{15}$ Due to national advertising opportunities afforded by the tobacco industry, major studios maximised exposure for their stars, who "sold" the studios' pictures to the public, in promotional broadsides timed to the opening dates of their large budget " $\mathrm{A}$ " class films.

\section{American Tobacco exploits "talkies", 1927}

American Tobacco, one of the leading cigarette companies of its day, ${ }^{16}$ was well positioned to out-advertise its competition using innovative multimedia campaigns. Retained by American Tobacco in 1925, ${ }^{16}$ Lord \& Thomas advertising agency by 1927 also represented Radio Corporation of America (RCA), the parent corporation of the National Broadcasting Company, and RKO, an RCA subsidiary and one of Hollywood's major film studios. ${ }^{17}$ Later, Paramount Pictures, another major studio, became a client of Lord \& Thomas. ${ }^{16}$ One of the largest advertising agencies, Lord \& Thomas ran American Tobacco's campaigns until its successor entity, Foote Cone \& Belding, resigned the account in 1948.

Following Warner Bros' 1927 release of The Jazz Singer, the world's first synchronised "talking picture" that made movies into a mass phenomenon, American Tobacco sought Hollywood endorsements for an ongoing campaign that claimed Lucky Strike spared smokers' throats and protected their voices (table 1). The focus on show business and its personalities differentiated American Tobacco's celebrity testimonials from other tobacco companies, which weakly copied American Tobacco's innovation before the 1940s. In a 1928 Lucky Strike advert featuring actor Jimmy Gleason's testimonial and plugging his Broadway show, Gleason stated, "[Lucky Strike] is certainly the cigarette of the acting profession". ${ }^{18}$ American Tobacco documents contain dozens of testimonials, authored by Lord \& Thomas but signed by famous names in vaudeville and the legitimate theatre, including composer George Gershwin, producer Sam Harris, actress Helen Hayes and Jazz Singer star Al Jolson (fig 2A).

Since the transition to sound was just beginning, Hollywood film directors were the first film figures to appear in Lucky Strike advertisements (table 2). The major studio employing the director authorised his testimonial, written by the advertising
Figure 1 Hollywood endorsements in cigarette advertising were pervasive from 1927-1951. The number of unique endorsements reflects the number of Hollywood testimonials received and used in advertising that could be counted in existing records of print adverts and radio broadcast transcriptions from previously secret tobacco industry documents (total $=292$ ). American Tobacco Company dominated the early period of cross-promotional cigarette advertising for its Lucky Strike brand, most notably in the 1937-8 campaign that focused on the importance of voice to movie actors and directors. When American Tobacco fell under investigation by the Federal Trade Commission for its misleading advertising, Liggett \& Myers was free to conduct similar advertising campaigns for its Chesterfield brand during the late 1940s.

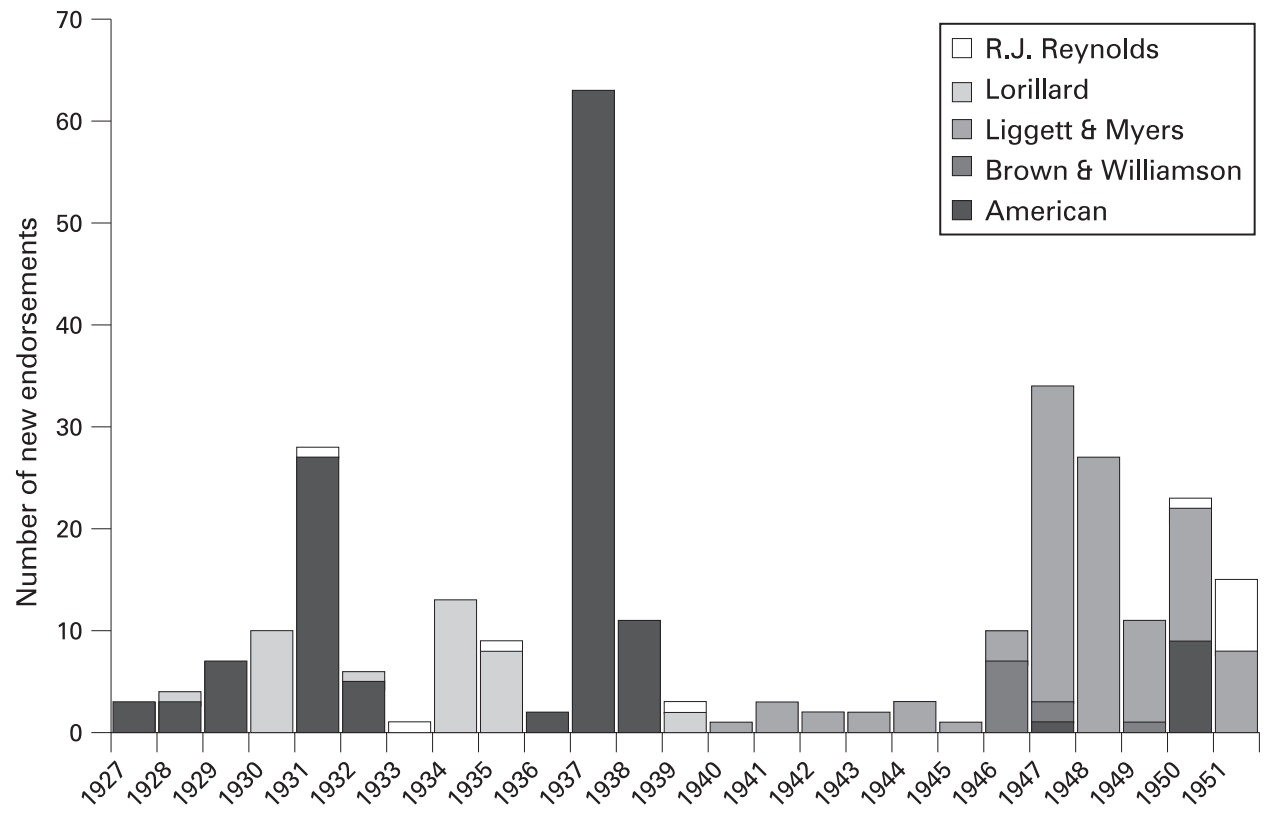


A

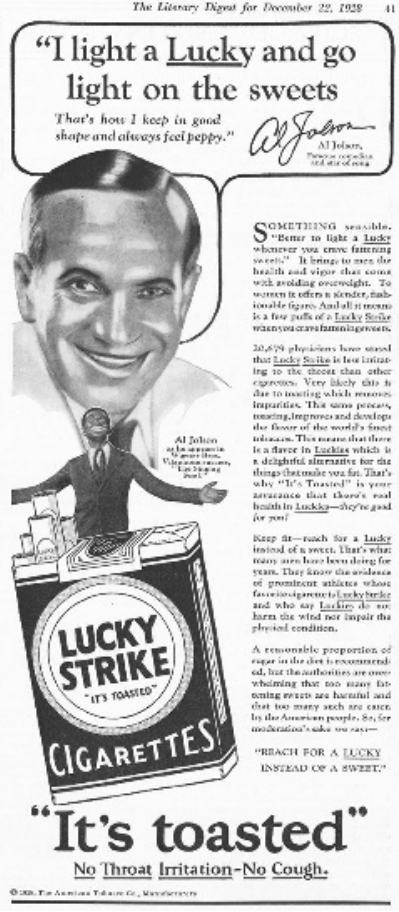

B

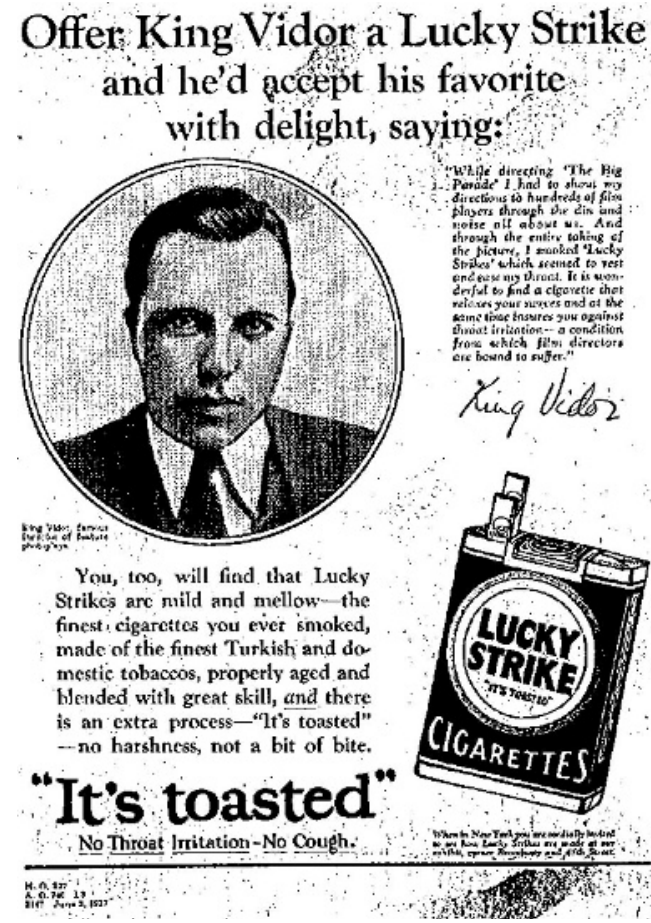

C

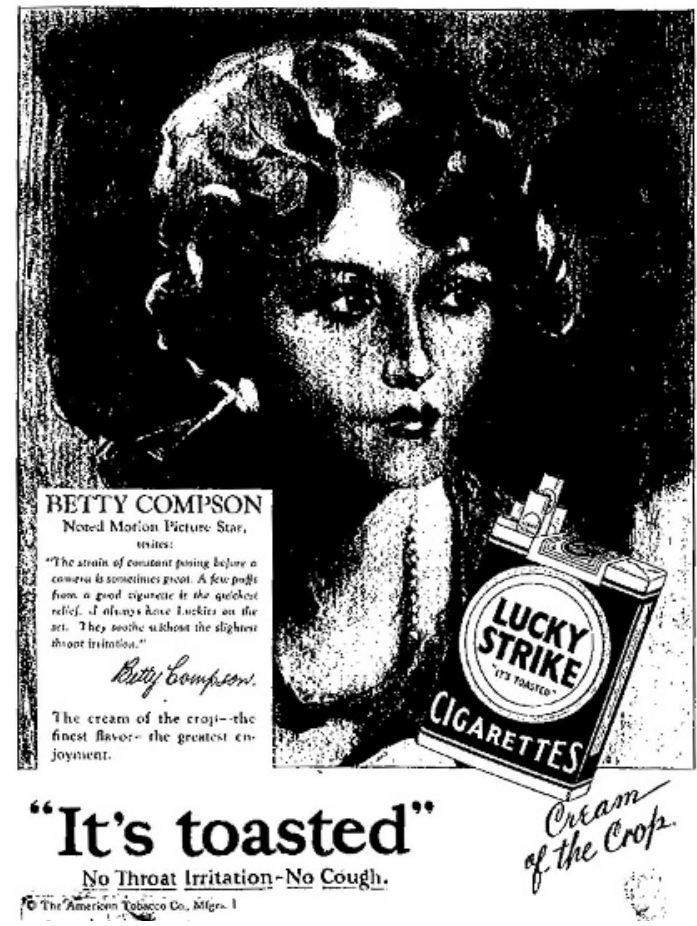

Figure 2 Hollywood movie stars and directors endorse Lucky Strike cigarettes. A. Al Jolson, the famous actor/singer star of the first talking picture, The Jazz Singer (1927), appeared in this 1928 advertisement endorsing Lucky Strike as an alternative to fattening sweets. In smaller print, the studio tie-in states, "Al Jolson, as he appears in Warner Bros Vitaphone success, "The Singing Fool [1928]"'”. This advertisement belonged to the "Reach for a Lucky Instead of a Sweet" campaign in 1928-1929. ${ }^{103}$ B. King Vidor, a prominent film director, endorsed Lucky Strike cigarettes for their soothing qualities in this 1927 "Precious Voice" campaign advertisement. Vidor's testimonial includes tie-in for his movie, The Big Parade (1925). ${ }^{20}$ C. Betty Compson, a successful actress who made the crossover to sound, endorsed Lucky Strike (commonly known as "Luckies") in this 1928 advertisement in the "Cream of the Crop" series. Compson's testimonial describes the relief she gets from smoking Luckies, which she always has on hand "on the set". ${ }^{104}$

agency, and ensured mention of the title of the director's motion picture to be promoted in the ad. ${ }^{19}$ Metro-GoldwynMayer (MGM) director King Vidor was featured in a 1927 advert that included his photograph, signature, plug for his silent film hit The Big Parade, and testimonial stating: "It is wonderful to find a cigarette that relaxes your nerves and at the same time insures you against throat irritation-a condition from which film directors are bound to suffer" ${ }^{\prime 20}$ (fig 2B). The cross-promotion pattern was set in these early adverts.

Lucky Strike's 1927 campaign also associated attractive qualities of female actors and their voices with smoking Luckies. ${ }^{20}$ Lord \& Thomas used "good, wholesome American actresses like Alice Brady" in a campaign that was, according to Fortune magazine, "so well timed...that public cigarette smoking by women in America can be correctly dated from [1927]". ${ }^{16}$ Placed above the headline, "The Captivating Voice of the Delightful Actress, Alice Brady", Brady's testimonial read, "I use Lucky Strikes, as I find they not only protect my voice but afford me the greatest amount of genuine enjoyment". ${ }^{20}$ Stage and screen actress Betty Compson signed a testimonial that read, "The strain of constant posing before a camera is sometimes great...I always have Luckies on the set"19 (fig 2C).

\section{Federal Trade Commission scrutinises cigarette advert testimonials, 1929}

Protesting Lucky Strike's 1928 endorsement adverts bearing the slogan, "Reach for a Lucky instead of a sweet", the US candy industry lobbied federal regulators to restrict American
Tobacco's use of this phrase. ${ }^{42}$ The Federal Trade Commission concluded that American Tobacco's advertising was misleading in several respects. ${ }^{43}$ Some Lucky Strike testimonials were from non-smokers, while others were not written or reviewed by the celebrities represented as making them. ${ }^{44}$ The FTC specifically cited the endorsement credited to Jazz Singer star Al Jolson:

Talking pictures demand a very clear voice...Toasting kills off all the irritants, so my voice is as clear as a bell in every scene. Folks, let me tell you, the good old flavor of Luckies is as sweet and soothing as the best "Mammy" song ever written...There's one great thing about the toasted flavor...it surely satisfies the craving for sweets. That's how I always keep in good shape and always feel peppy. ${ }^{44}$

The FTC found that American Tobacco had authority to use this statement, and paid for it, but that Jolson did not prepare or review it ${ }^{44}$ before its use in a 1928 Lucky Strike Radio Hour broadcast. ${ }^{45}$ Instead, Warner Bros' advertising manager A P Waxman ${ }^{46}$ signed a release on Warner Bros letterhead for text similar to what was used on air, stating that he acted on Jolson's behalf. ${ }^{18}$

In November 1929, the FTC issued a cease and desist order against American Tobacco, prohibiting testimonials unless written by the endorser, whose opinions were "genuine, authorised and unbiased". ${ }^{44}$ The FTC ordered American Tobacco to conspicuously disclose payments for testimonials in its advertising. ${ }^{44}$ However, American Tobacco successfully removed this disclosure stipulation in $1934 .{ }^{44}$ No tobacco 
Table 1 Cigarette advertising campaigns using actor endorsements, 1927-1950

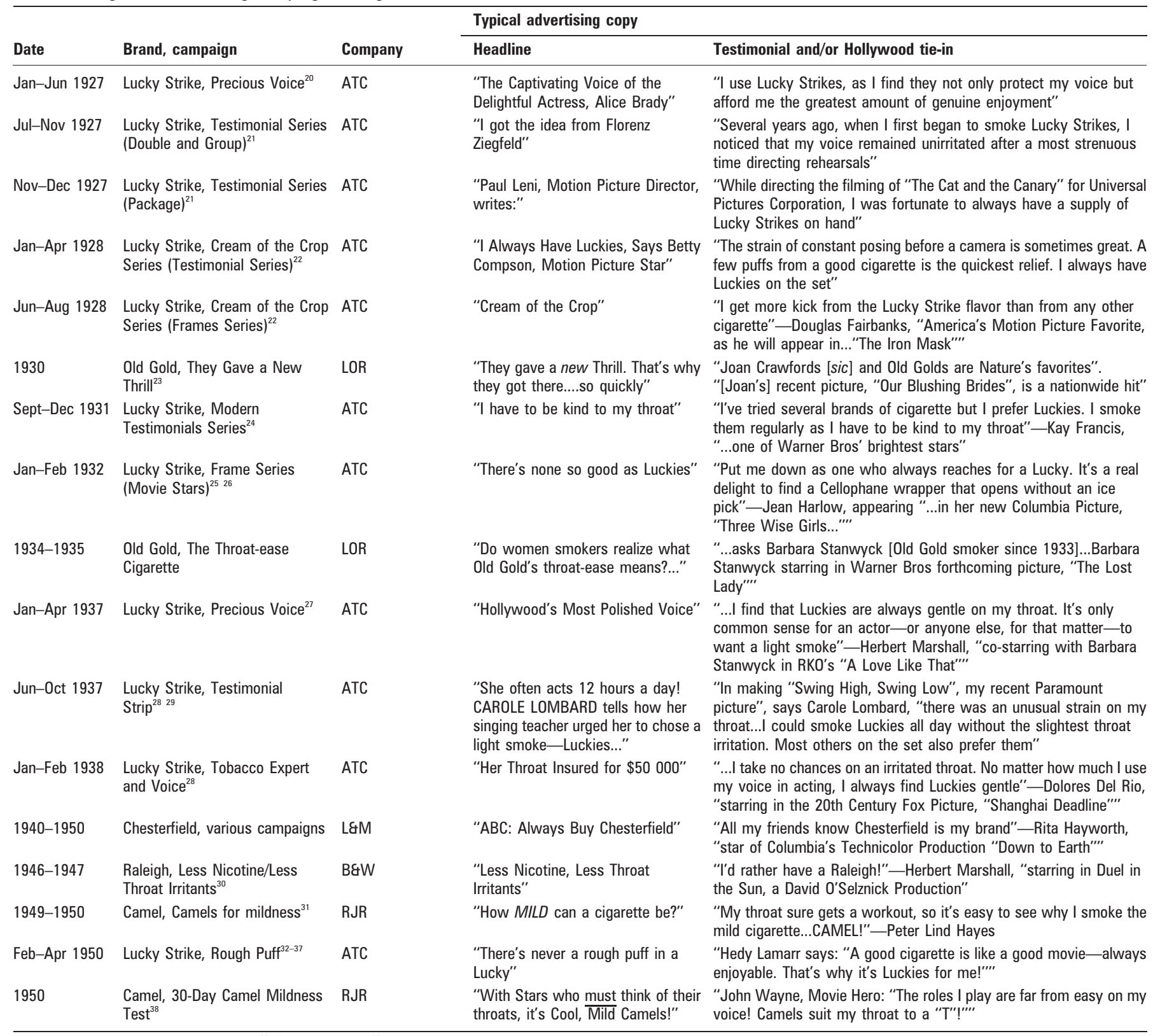

Source: American Tobacco Company, ${ }^{39-41}$ RJ Reynolds ${ }^{38}$ Jackler Collection.

"Luckies" is a name often used to refer to the Lucky Strike brand. ATC, American Tobacco Company; B\&W, Brown \& Williamson; L\&M, Liggett \& Myers; LOR, Lorillard; RJR, RJ Reynolds.

company acknowledged in its print adverts or radio broadcasts that advertising testimonials were bought or that an advertising agency drafted them. ${ }^{47}$

\section{Lucky Strike revives the Hollywood testimonial, 1931}

American Tobacco revised the contractual language for its 1931 endorsement campaign to ensure control over the language and messaging of the testimonials, while still conforming to the FTC's 1929 stipulations that endorsers supply the testimonial. ${ }^{48}$ Actors signed a revised release that read:

No monetary or other consideration of any kind or character has been paid me or promised me for the above statement, by Mr.

[American Tobacco's agent] or by the manufacturers of Lucky

Strike Cigarettes or otherwise. ${ }^{19}$

While actors offered their opinions and declared the number of years they smoked Luckies, they permitted Lord \& Thomas to write the actual testimonial, "phrased in such form as to make an effective message from the standpoint of truthfulness and advertising value". ${ }^{48}$

American Tobacco's endorsement contracts also specified the use of the stars' names, photographs and conspicuous mention of film title and studio "in advertisements of LUCKY STRIKE Cigarettes, in newspapers, magazines, on billboards, over the radio and/or in any other media of advertising". ${ }^{48}$ Before publication, the studios reviewed and approved all advertising copy, including any other names mentioned in connection with the star, studio or motion picture plugged. In 1931, for example, Warner Bros and Paramount publicists sent letters to fan magazine Photoplay approving use of co-stars and star's spouses in specific Lucky Strike adverts. ${ }^{48}$ (Photoplay acted as one of American Tobacco's agents in securing 1929-1931 Hollywood endorsements, reportedly in exchange for an advertising appropriation of the 2008 equivalent of US\$694 000.) $)^{48-50}$ 
However, to participate in this lucrative partnership, the studios bypassed their own ban on actor endorsements, promulgated in 1931 by the Motion Picture Producers and Distributors of America (MPPDA, precursor to the Motion Picture Association of America (MPAA)). ${ }^{51}$

Following publicity from the 1929 FTC inquiry and the MPPDA's 1931 rule against paid endorsements by stars, the 1931 Lucky Strike campaign explicitly denied that endorsers were bought. A newspaper advert featuring Mary Astor, a Radio Pictures contract player, asked:

Is Miss Astor's Statement Paid For? You may be interested in knowing that not one cent was paid to Miss Astor to make the above statement. Miss Astor has been a smoker of Lucky Strike cigarettes for over a year. We hope the publicity herewith given will be as beneficial to her and to Radio Pictures, her producers, as the endorsement of LUCKIES is to you and to us. ${ }^{24}$

This explanation reassured the reader and suggested that American Tobacco made arrangements with the studios that contractually controlled the endorsements from its actors, rather than with actors directly. The statement also spotlights the cross-promotional value of cigarettes to Astor's studio employer, perhaps to aid American Tobacco in soliciting cooperation from other studios.

\section{Lucky Strike's new Hollywood campaign, 1937-8}

With the 1934 removal of the FTC's stipulation that testimonial payments be disclosed, the process of buying testimonials from top stars was discussed openly in 1937 meeting minutes and memoranda from Lord \& Thomas' Lucky Strike Group. ${ }^{52-57}$ The advertising agency set the price of the endorsement, then determined the endorser's smoking status, brand preference and willingness to endorse Lucky Strike. An interview protocol captured the prospect's answers to key questions, without closing the doors to a testimonial:

1. Does signer smoke Luckies?

2. Does signer smoke Luckies exclusively?

3. If answer to Question 2 is "No:"

(a) does the signer smoke Luckies consistently and other brands occasionally?

(b) will signer give full preference in smoking to Luckies henceforth? ? $^{58}$

For Hollywood and American Tobacco, the 1937-8 Lucky Strike campaign was based on "mutual using". 525960 Each studio aimed to maximise its exposure in national cigarette campaigns, for competitive advantage over other studios. American Tobacco aimed to exploit Hollywood's top stars, regardless of their studio affiliation. For Lord \& Thomas, the interests of the stars and studios were secondary to Lucky Strike's sales goals.

Table 2 Hollywood directors in Lucky Strike adverts, 1927-8

\begin{tabular}{lll}
\hline Name & Studio affiliation & Known for: \\
\hline Herbert Brenon & Paramount & Sorrell and Son (1927) \\
Allan Dwan & Fox and others & Sands of Iwo Jima (1949) \\
Paul Leni & Universal & The Cat and the Canary (1927) \\
Fred Niblo & MGM and others & Ben-Hur (1925) \\
Albert Parker & United Artists & The Black Pirate (1926) \\
Edward Sutherland & Paramount and others & Abie's Irish Rose (1946) \\
King Vidor & MGM and others & Duel in the Sun (1946) \\
Raoul Walsh & Various & Sadie Thompson (1928) \\
\hline
\end{tabular}

Source: American Tobacco, ${ }^{19}{ }^{21}$ and http://IMDbPro.com.
Albert Lasker, president of Lord \& Thomas, reminded his Lucky Strike Group in January 1937:

[T] he most important thing about this campaign, gentlemen, is what we say in the testimonials. That's where we do our selling...This is a most serious thing and requires much concentration and thought. ${ }^{52}$

The Lucky Strike Group also tried to balance the studio's requirement of a "plug" with the agency's desire to focus the reader on the Lucky Strike message, as evident in the minutes of a meeting held by members of the Lucky Strike Group at Lord \& Thomas:

GRIFFIN: In all cases, we would like to get the plug for the thing a certain person intends to be plugged for, in the testimonial. COONS: That's a good point. But, it must be done in a clever way, and everything must be sincere and completely believable... GRIFFIN: ...I think the policy on the plugs should be that there will be put in a plug for their show or activity only if they require it or if their particular reference is of interest by itself in the testimonial.

COONS: In other words, we don't want to put a plug in about a class " $\mathrm{B}$ " picture no one is ever going to see.

Accordingly, Lucky Strike underwrote national advertising for more than one in five "A" class (big budget, top bill) pictures released in 1937 by the major studios, including 35 films from MGM, Paramount, RKO and Warner Bros (table 3). ${ }^{61}$ The movie tie-in and publication timing of Lucky Strike adverts were coordinated with the studios to deliver maximal promotional value. Proofs of Lucky Strike newspaper adverts are frequently dated a few days before a film's opening in New York and other major cities. ${ }^{62}$ For example, in April 1937, Lord \& Thomas informed movie star Gary Cooper that his magazine advert scheduled for "late June and early July" would "make mention of your Paramount Picture "Souls at Sea", ...Further we want to postpone your broadcast [on an American Tobacco-owned radio show] to a time shortly before the release of your Goldwyn picture "The Adventures of Marco Polo"'", ${ }^{63}$

Besides spending millions of dollars on advertising space and radio time to promote stars, their films and studios, American Tobacco paid Hollywood stars themselves at least US\$218 750 (equivalent to US\$3.2 million in 2008) in 1937 and 1938 to

Table 3 US film studios engaged in tobacco cross-promotion, 1928-51

\begin{tabular}{|c|c|c|}
\hline & Period & $\begin{array}{l}\text { Extant adverts with } \\
\text { studio plug }\end{array}$ \\
\hline \multicolumn{3}{|l|}{ Major studios: } \\
\hline Paramount & 1931-1951 & 53 \\
\hline Warner Bros & 1928-1950 & 34 \\
\hline Fox & 1931-1951 & 29 \\
\hline MGM & 1930-1951 & 28 \\
\hline RKO & 1931-1937 & 21 \\
\hline Columbia & 1931-1951 & 19 \\
\hline United Artists & $1931-1949$ & 18 \\
\hline Universal & 1931-1951 & 13 \\
\hline Major studios total & & 215 \\
\hline Smaller studios & & 19 \\
\hline $\begin{array}{l}\text { Hollywood testimonial adverts } \\
\text { without explicit studio plugs }\end{array}$ & & 64 \\
\hline \multicolumn{3}{|c|}{$\begin{array}{l}\text { Smaller studios include David O Selznick, Enterprise, Eagle-Lion, First National, Pathé, } \\
\text { Samuel Goldwyn, Santana and Radio Pictures. Total number of adverts containing } \\
\text { studio plugs is a conservative estimate based on surviving records. An advertisement } \\
\text { was counted if the studio name appeared in print or was mentioned on a tobacco } \\
\text { company-sponsored radio program during the guest appearance of the Hollywood } \\
\text { endorser. }\end{array}$} \\
\hline
\end{tabular}


endorse Lucky Strikes in print adverts and on radio programs owned by American Tobacco (table 4). Top "A list" stars endorsing Lucky Strike were each paid US\$73000 (2008 equivalent) for their testimonial and benefited from national exposure-making them even more valuable to the studios and attractive to other national advertisers. American Tobacco often split payments into up front and year-end portions ${ }^{63}$ to ensure appearances by the stars on radio broadcasts, but several top stars negotiated a lump sum. Stars frequently extended their 1year Lucky Strike agreements and presumably received a repeat payment to endorse Lucky Strike exclusively. ${ }^{63}$ In a standard agreement, American Tobacco supplied the actor with Lucky Strikes for a year, ${ }^{63}$ a modest gift for stars at this income level. Free cigarettes might have aided publicity or served as evidence that the star valued and smoked the brand, should these arrangements again be investigated.

The Lucky Strike campaign was not Hollywood's only collaboration with tobacco advertisers. In 1937, American Tobacco bought US\$58 000 worth of time (equivalent to US\$872 546 in 2008) for seven in-theatre commercials that starred non-studio affiliated performers Genevieve Tobin and Buddy Rogers. ${ }^{64}{ }^{65}$ These commercials were primarily shown in independent theatres following a 1931 MPPDA decision to discourage advert films, which had received enough public backlash that the MPPDA feared further federal regulation. ${ }^{51}$ Before the MPPDA's ruling, Paramount and Warner Bros had tested single-reel advertising films and planned to charge national advertisers a set price per 1000 viewers in the studioowned theatre chains. ${ }^{66}$ The New York Times calculated that Liggett \& Myers would have paid Paramount US\$325 000 (equivalent to US $\$ 4.5$ million in 2008) for a 13 -film series advertising Liggett \& Myers cigarettes. ${ }^{66}$

\section{Studios control deals with contract stars}

While American Tobacco paid for national Hollywood campaigns, studio talent contracts gave studios complete control over the use of their celebrity "brand names". Major studios negotiated the content of testimonials, insisted that the timing of adverts and radio appearances be coordinated with movie releases, and denied permission for deals that did not serve their interest. Paramount wrote to Lord \& Thomas in September 1931, authorising "the use of a star's name, likeness and testimonial" and stipulating that "all advertising, publicity, and exploitation matter [of Lucky Strike Cigarettes] mentioning the name or showing a likeness of [the actor] must first be submitted to this corporation for written approval before being used". ${ }^{67}$ MGM, too, informed Lord \& Thomas in July 1937, "It is important no advertisements are to be scheduled for publication until approval has been given by us, and until any changes we may wish to make concerning picture credit have been completed". ${ }^{63}$ MGM also exercised power when it denied Clark Gable's guest appearance on an American Tobacco radio show. ${ }^{69}$ Still, Lord \& Thomas paid the balance promised to Gable and extended his Lucky Strike endorsement contract for another year. ${ }^{69}$

In July 1937, RKO permitted contract player Herbert Marshall to endorse Lucky Strike "upon the following conditions":

(a) ...[Y]ou will be announced as "Herbert Marshall, now costarring with Barbara Stanwyck in RKO's motion picture "A Love Like That" or if the name of the motion picture "A Love Like That" is subsequently changed, the changed title will be inserted; (b) That in connection with magazine advertisements the said motion picture "A Love Like That" will also be announced and that the magazine advertisements will be released contemporaneously with the release of the said motion picture;

(c) That wherever possible, said motion picture will be announced in connection with the Lucky Strike Hit Parade radio hour. ${ }^{63}$

Correspondence detailing similar promotional specifications are preserved from Selznick International Pictures, ${ }^{80}$ Warner Bros, ${ }^{80-82}$ United Artists, ${ }^{83}$ The Samuel Goldwyn Company, ${ }^{83}$ 20th Century Fox Film ${ }^{84}$ and Paramount. ${ }^{19} 85$

\section{Radio says Hollywood smokes Luckies, 1937}

In the fall of 1937, coinciding with Lucky Strike's Hollywood campaign, Lord \& Thomas paid Warner Bros US\$935 $000^{86}$ (equivalent to US\$13.7 million in 2008) to create Your Hollywood Parade, an hour-long weekly radio show for American Tobacco broadcasted from the Warner Bros lot. The program strung together acted out scenes from upcoming Warner Bros movies, according to the production agreement:

There shall be no previews of motion pictures other than Warner Bros pictures...Each such preview...shall as far as possible be presented by the stars or featured players featured in such Warner Bros picture...In addition, Warner Bros...agree to furnish such other members of their organization as may be selected by mutual consent to provide motion picture studio atmosphere, it being intended that the entire personnel of Warner Bros, except executives, shall be available for this purpose. ${ }^{87}$

For its part, Warner Bros declared, "Warner Bros believes that it will be to its advantage to cooperate in the broadcasting of such a program", which was created at American Tobacco's expense. Lord \& Thomas supervised all aspects of the show and could cancel it if Warner Bros' cooperation was unsatisfactory, or for any other reason.

American Tobacco's radio programs were hard sell: in 1943, an American Tobacco radio producer catalogued 268 "Lucky Strike impressions" in 135 min of broadcast time, the equivalent of hearing the Lucky Strike brand name or jingle every 30 s. $^{88}$ On Your Hollywood Parade, Warner Bros stars appeared, often delivering their testimonial, in Lucky Strike commercials delivered by emcee Dick Powell, a Warner Bros contract actor. The radio show reinforced the impression, also encouraged by the print campaign, that everyone in Hollywood smoked Lucky Strike-and that cigarettes seen onscreen were Luckies. For example:

I once asked a "property" man-who supplies cigarettes to the actors-what the favorite is. He answered by opening up a box containing cigarettes. In it were nothing but Luckies.-

Testimonial signed by Miriam Hopkins, February 3, $1937 .{ }^{63}$

It's always easy for me to get a Lucky from Joan Crawford or Clark Gable, or even from most of the newcomers to the studio...So, all in all, you can see I'm really enthusiastic.Statement signed by Myrna Loy, December 28, $1937 .{ }^{63}$

In 1944, American Tobacco created The Jack Benny Program, contracting with the top-rated comic to deliver $10530 \mathrm{~min}$ radio shows over 3 years for US $\$ 2.3$ million (US $\$ 27.6$ million in 2008). American Tobacco also deposited US\$600 000 (US\$7.2 million in 2008) into a "Special Exploitation Fund" to use as:

[T] he Contractor [Benny]...in his sole discretion may deem proper, including (but not limited to) for purposes of paying the compensation of guest artists who appear on the broadcasts (the 
Table 4 Lucky Strike's paid Hollywood endorsements, 1937-8

\begin{tabular}{|c|c|c|c|}
\hline Actor & Movie(s) and studio(s) promoted & Payment (US\$) & 2008 value (US\$) \\
\hline Beery, Wallace ${ }^{70}$ & The Mad Man of Brimstone (MGM) & $\$ 10000$ & $\$ 146583$ \\
\hline Bennett, Constance ${ }^{63}$ & Topper (MGM) & $\$ 6000$ & $\$ 87950$ \\
\hline Boyer, Charles ${ }^{71}$ & Tovarich (Warner Bros) & $\$ 3000$ & $\$ 43975$ \\
\hline Carroll, Madeleine ${ }^{63}$ & The Prisoner of Zenda (Selznick) & $\$ 3000$ & $\$ 43975$ \\
\hline Claire, Marion ${ }^{62}$ & & $\$ 750$ & $\$ 10994$ \\
\hline Colbert, Claudette $^{63}$ & Maid of Salem (Paramount), I Met Him in Paris (Paramount) & $\$ 10000$ & $\$ 146583$ \\
\hline Cooper, Gary ${ }^{63}$ & The Adventures of Marco Polo (MGM), Souls At Sea (Paramount) & $\$ 10000$ & $\$ 146583$ \\
\hline Crawford, Joan ${ }^{63}$ & The Bride Wore Red (MGM) & $\$ 10000$ & $\$ 146583$ \\
\hline Eilers, Sally ${ }^{47}$ & We Have Our Moments (Universal) & $\$ 3000$ & $\$ 43975$ \\
\hline Fonda, Henry ${ }^{72}$ & & $\$ 3000$ & $\$ 43975$ \\
\hline 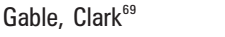 & Saratoga (MGM) & $\$ 10000$ & $\$ 146583$ \\
\hline Gaxton, William ${ }^{62}$ & & $\$ 1250$ & $\$ 18323$ \\
\hline Hope, Bob ${ }^{72}$ & & $\$ 2500$ & $\$ 36646$ \\
\hline Hopkins, Miriam ${ }^{63}$ & The Woman I Love (RKO) & $\$ 5000$ & $\$ 73292$ \\
\hline Lawrence, Gertrude $^{68}$ & & $\$ 1750$ & $\$ 25652$ \\
\hline Lombard, Carole ${ }^{63}$ & $\begin{array}{l}\text { Swing High, Swing Low (Paramount), True Confession } \\
\text { (Paramount) }\end{array}$ & $\$ 10000$ & $\$ 146583$ \\
\hline Loy, Myrna ${ }^{63}$ & Man Proof (MGM), Double Wedding (MGM) & $\$ 10000$ & $\$ 146583$ \\
\hline MacMurray, Fred ${ }^{59}$ & Exclusive (Paramount) & $\$ 6000$ & $\$ 87950$ \\
\hline Marshall, Herbert ${ }^{63}$ & Angel (Paramount), A Love Like That (RKO) & $\$ 10000$ & $\$ 146583$ \\
\hline McLaglen, Victor ${ }^{59}$ & $\begin{array}{l}\text { Cavalcade (20th Century Fox), Wee Willie Winkie (20th Century } \\
\text { Fox) }\end{array}$ & $\$ 6000$ & $\$ 87950$ \\
\hline Merivale, Philip ${ }^{59}$ & & $\$ 3000$ & $\$ 43975$ \\
\hline Michael, Gertrude ${ }^{59}$ & & $\$ 2000$ & $\$ 29317$ \\
\hline Milland, Ray ${ }^{59}$ & & $\$ 2000$ & $\$ 29317$ \\
\hline $\begin{array}{l}\text { Montgomery, } \\
\text { Robert }^{59}\end{array}$ & Live, Love, and Learn (MGM) & $\$ 10000$ & $\$ 146583$ \\
\hline Nagel, Conrad ${ }^{73}$ & & $\$ 1500$ & $\$ 21988$ \\
\hline Navarro, Ramon ${ }^{73}$ & & $\$ 1500$ & $\$ 21988$ \\
\hline Powell, Richard ${ }^{59}$ & Hollywood Hotel (Warner Bros) & $\$ 5000$ & $\$ 73292$ \\
\hline Raft, George ${ }^{74}$ & & $\$ 3000$ & $\$ 43975$ \\
\hline Raymond, Gene ${ }^{74}$ & Three on A Latchkey (RKO) & $\$ 3000$ & $\$ 43975$ \\
\hline Rhodes, Erik ${ }^{74}$ & & $\$ 2000$ & $\$ 29317$ \\
\hline Robinson, Edward ${ }^{74}$ & Kid Galahad (Warner Bros) & $\$ 3000$ & $\$ 43975$ \\
\hline Ross, Shirley ${ }^{74}$ & & $\$ 3000$ & $\$ 43975$ \\
\hline Ruggles, Charles ${ }^{74}$ & Turn Off the Moon (aka Honeymoon Cottage) (Paramount) & $\$ 3000$ & $\$ 43975$ \\
\hline Sothern, $\mathrm{Ann}^{75}$ & She's Got Everything (RKO), Don't Forget to Remember (RKO) & $\$ 3000$ & $\$ 43975$ \\
\hline Stanwyck, Barbara ${ }^{76}$ & The Plough and the Stars (RKO) & $\$ 10000$ & $\$ 146583$ \\
\hline Sullivan, Margaret ${ }^{77}$ & & $\$ 10000$ & $\$ 146583$ \\
\hline Swanson, Gloria ${ }^{75}$ & & $\$ 1500$ & $\$ 21988$ \\
\hline Taylor, Robert ${ }^{63}$ & Broadway Melody of 1938 (MGM), Yank at Oxford (MGM) & $\$ 10000$ & $\$ 146583$ \\
\hline Tobin, Genevieve ${ }^{78}$ & & $\$ 3000$ & $\$ 43975$ \\
\hline Tracy, Spencer ${ }^{78}$ & Captains Courageous (MGM), Mannequin (MGM) & $\$ 10000$ & $\$ 146583$ \\
\hline Worth, Constance ${ }^{79}$ & & $\$ 2000$ & $\$ 29317$ \\
\hline Wyatt, Jane $^{79}$ & Lost Horizon (Columbia) & $\$ 6000$ & $\$ 87950$ \\
\hline Total & & $\$ 218750$ & $\$ 3208518$ \\
\hline
\end{tabular}

employment of guest artists from time to time being deemed desirable in connection with the exploitation of Sponsor [American Tobacco] and Sponsor's products)...it being expressly agreed that Contractor, in such advertising and exploitation, shall not be obligated to refer to or mention Sponsor or its products. ${ }^{89}$ (Emphasis added.)

The "Special Exploitation Fund" gave American Tobacco oversight and deniability for "guest star" Lucky Strike commercials. Channelling endorsement fees through the program's producer may have temporarily avoided scrutiny by the FTC, which had launched another investigation into cigarette advertising in 1942. ${ }^{90}$ A sketch between Benny and Lauren Bacall on a January 1947 broadcast of The Jack Benny
Program ${ }^{91}$ seamlessly promotes Lucky Strike and Bacall's new film (fig 3).

\section{Chesterfield goes to Hollywood, 1946}

When the FTC began investigating advertising methods of American, Lorillard and Reynolds in 1942 (Reynolds specifically for its Camel testimonial payments ${ }^{92-94}$ ), Liggett \& Myers, makers of Chesterfield and the third largest cigarette company at the time, launched a multiyear Hollywood testimonial campaign in print and on radio, spending US\$4.7 million (US\$50.9 million in 2008) in 1946 alone. ${ }^{95}$ That year, Liggett spent more to advertise Hollywood than Paramount, 20th 
Figure 3 Perception of brand preference and use among Hollywood stars were supported by radio endorsements.

American Tobacco's Lucky Strike brand sponsored The Jack Benny Program from the mid-1940s to mid-1950s. This radio transcription from the January 5, 1947 broadcast is an example of a guest appearance and testimonial, given here by actress Lauren Bacall. Bacall mentions Lucky Strike is her favourite brand of cigarette. Stating her brand preference may have served to create an association between Lucky Strike and onscreen smoking by Bacall's characters (not to mention in real life). The transcription also shows that Bacall's guest appearance included a "sketch based on [her Warner Bros] picture "To Have and Have Not"'" (1944), which co-starred Humphrey Bogart. Source: American Tobacco Company. ${ }^{91}$
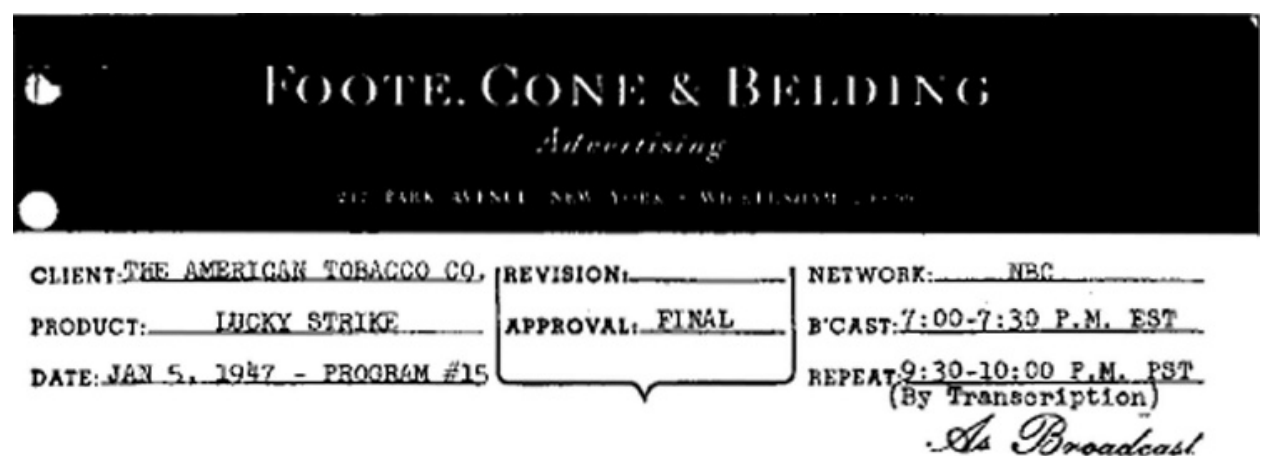

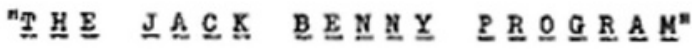

JACK:

Yos, yes. We21, Louron ... Laurcn, shall ve start rohesrsing?

BACALL: No hurry, no hurry ... Hove jou got a cigarottc?

JS.CK:

BACALL:

JACK:

A oigarotte ... Yos yes ... hero you are.

Thanks ... Match?

Noteh ... You knov Lauron, that of gsrette I gave you is

a Lucks Strike.

BACALL: I know and it's my ravor1to brand, too.

JACK:

Really?

BACALL: .. YCs ... They're so round ... So fire ... so rilly

pecked ... Bo froe and casy on tho drav.

JACK: Goo ... F. E. Boono never sounded like thet ... Oosh,

Leurcen ... I cen just pieture you in a bathing sult ...

holding up that big tobecoo lear ... And you knox,

Lauren, Lucky Strikes aro mede of that rine, that 11ght, that nstursily mild tobscoo.

BACALL: Wel2, what do you knox ... and I thought mothor told wo evorything.

JACK: Well, live and learn.

BAChLL: You must havo learned a lot.

JACK: Yes yes ... Now let's stert rchoaraing ... Here's jour

soript ... We 're going to do a akotoh basod on your

ploture, "To Have and Hnve Not" ... You'll pley the same

part you did in the pleturo.
Century Fox, Warner Bros and Columbia Pictures-Liggett's main Hollywood studio beneficiaries - combined. ${ }^{95}$

Chesterfield gained endorsements from Hollywood stars who formerly endorsed Lucky Strikes, including Barbara Stanwyck, Claudette Colbert, Gary Cooper, Bob Hope and Ray Milland at Paramount, Clark Gable at MGM, Fred MacMurray at Universal and Joan Crawford at Warner Bros. On the Chesterfield Supper Club radio program, many stars, such as Stanwyck and Susan Hayward, had their testimonials read by an unidentified actor. Others, such as Fred MacMurray and Rosalind Russell, delivered the commercial themselves. No payments are documented in Liggett's files; presumably either the company or its advertising agency made arrangements directly with studios, or the payments to the stars were channelled through the radio show's producers, as American Tobacco did at The Jack Benny Program.

\section{DISCUSSION}

Smoking has appeared in movies since silent film, ${ }^{10}$ but the advent of "talking pictures" in the late 1920s marked the beginning of the American Tobacco Company's systematic exploitation of film celebrities. Nearly 200 movie actors are known to have simultaneously promoted a tobacco brand and their studios' releases from 1927-51; two-thirds of the top 50 box office stars in Hollywood from the late 1930s through the 1940s endorsed tobacco brands for advertising purposes. ${ }^{96}$ With these national testimonial advertisements, cigarette companies fostered the impression that cigarettes smoked by stars on 
screen were a specific brand. Tobacco companies, reported throughout this period to be targeting new women smokers to increase the size of the cigarette market, ${ }^{97} 98$ used female film stars to model behaviour and increase social acceptance through testimonial advertising and onscreen smoking. ${ }^{97} 99$

Major studios' talent contracts ${ }^{100101}$ allowed them to maximise marketing opportunities by closely controlling their stars' participation in some of the largest US advertising campaigns. Cross-promotion from cigarette advertising campaigns helped build studio brands, spotlight their biggest stars, and promote the big budget " $\mathrm{A}$ " class films at the top of theatre double bills. Tobacco campaigns also paid stars substantial sums while reinforcing the stars' notoriety, boosting their value to the studios and other national advertisers. Free cigarettes provided under endorsement agreements created publicity opportunities on and off the set-a tobacco industry strategy revived in the 1980s. ${ }^{9}$ Despite the studios' voluntary 1931 ban on product placement, the tobacco companies' multimedia testimonial campaigns linked particular brands with actors, effectively branding "generic" cigarettes in films by advertising actors' brand "preference".

The value of cigarette/movie tie-ins to the companies involved is difficult to monetise, but the fact that an estimated $20-25 \%$ of all major studios' feature-length " $\mathrm{A}$ " class motion pictures appeared in Lucky Strike advertising in 1937 indicates the financial importance of these tie-ins to the studios. ${ }^{14}$ To participate in this lucrative partnership, the studios' also repeatedly bypassed their own 1931 ban on actors' product endorsements. ${ }^{15}$ In turn, American Tobacco Company and Liggett \& Myers allocated portions of their multimillion US dollar budgets to print and radio campaigns featuring Hollywood stars, films and studios. This cultivated, synergistic relationship between Hollywood and the tobacco industry promoted social acceptance of smoking and, by explicitly and repeatedly associating Hollywood's top stars with cigarette brands, made their motion pictures an integral part of the tobacco industry's sales strategy.

By 1943, Reynolds, Liggett and American ranked among the nation's top 10 advertisers overall. The 6 largest cigarette companies spent the 2008 equivalent of US\$315 million to advertise that year, more than 10 times the US\$28 million spent by the 8 major Hollywood studios. ${ }^{13}$

\section{What this paper adds}

- Smoking in movies is associated with adolescent and young adult smoking initiation.

- Public health efforts to reduce exposure to onscreen smoking are countered with arguments that tobacco imagery in "classic" movies was integral to filmmaking artistry.

- The present work explores the mutually beneficial commercial collaborations between the tobacco companies and major motion picture studios from the late 1920 s to 1940 s. We found endorsement contracts that reveal American Tobacco Company paid movie stars for their testimonials and negotiated cross-promotion with the studios to which the stars were contracted.

- The synergistic relationship between US tobacco and motion picture industries described in the present work grew out of cross-promotion incentives, and continues to perpetuate public tolerance of onscreen smoking.
The tobacco and film industries' mutual exploitation was not entirely unconstrained. Cigarette advertising provoked repeated federal inquiries into product claims and endorsement deals. Public criticism of product placement in films and commercials in theatres prompted self-regulatory policies from major studios. Tobacco companies adapted to increasing regulation and scrutiny by making legally prudential changes on paper, but continued to write and pay for endorsements.

Several factors may explain the decline of smoking frequency in US films after 1950 and until 1980, ${ }^{102}$ including publicity about diseases linked to smoking, the rapid penetration of advertising-driven television and the consequent shift of tobacco advertising and sponsorship dollars, and the breakdown of studio control over stars and theatre networks.

The legacy of cross-promotion during the "Golden Age" of Hollywood, led by American Tobacco and its advertising agency, Lord \& Thomas, continues to be used to rationalise smoking as integral to the art of film making. Evidence suggests that this integration was a commercial collaboration "signed, sealed and delivered" (as Lucky Strike endorsement agreements from the 1930s put it) by the tobacco companies, major studios and many of the era's best remembered stars. The failure of federal regulations and voluntary film industry policies to resist tobacco-film industry cross-promotion during the mid-20th century was followed by an increase in onscreen tobacco incidence after 1980, despite exposure of tobacco industry practices with the 1989 Congressional inquiry on product placement and nominal limitations in the 1998 Master Settlement Agreement.

Whereas legal and regulatory approaches, along with appeals to film "creatives" who lack control over film content and product placements, have failed to break the deliberately fostered association between Hollywood films and cigarettes since 1927, current broad-based efforts to create market disincentives within the film industry, specifically by rating future smoking "R", could prove more effective.

The presumption promoted by those who oppose rating future smoking " $\mathrm{R}$ " is that mainstream motion pictures are an art form into which social agendas should not intrude. The pattern of close cooperation between the film and tobacco industries, from the advent of sound in 1927 to the transfer of tobacco sponsorship to television starting in the late 1940s and the re-emergence of film-tobacco deals after tobacco adverts were barred from television in the 1970 s, suggests instead that the motion picture industry was always ready to cater to the tobacco industry's commercial agenda.

As in the 1930s, nothing today prevents the global tobacco industry from influencing the film industry in any number of ways to achieve its own strategic objectives. It would be more accurate to view motion pictures (and video programming) not as disinterested artistic works but as commercial platforms (which occasionally achieve the status of art) serving a variety of agendas, not all of which - as in the case of product placement deals struck by producers - consistently respect the work's artistic integrity or the unsuspecting audience in search of entertainment or inspiration. Policy makers who recognise the historic and contemporary role played by Hollywood films in expanding and renewing the market for tobacco products should not hesitate to modernise rating systems to exclude smoking from films marketed to youth, thereby taking steps necessary to break the long standing commercial connection between movies and smoking. 
Funding: This work was funded by National Cancer Institute Grant CA-87472. The sponsor had no role in the conduct of the research or the preparation of the manuscript.

Competing interests: None.

\section{REFERENCES}

1. Charlesworth A, Glantz SA. Smoking in the movies increases adolescent smoking: a review. Pediatrics 2005:116:1516-28.

2. Institute of Medicine. Ending the tobacco problem: a blueprint for the nation Washington, DC: National Academies Press, 2007

3. Dalton M, Sargent J, Beach M, et al. Effect of viewing smoking in movies on adolescent smoking inititation: a cohort study. Lancet 2003;362:281-5.

4. Wills T, Sargent J, Stoolmiller M, et al. Movie smoking exposure and smoking onset: a longitudinal study of mediation processes in a representative sample of US adolescents. Psychol Addict Behav 2008;22:269-77.

5. Song AV, Ling PM, Neilands TB, Glantz SA. Smoking in movies and increased smoking among young adults. Am J Prev Med 2007;33:396-403.

6. Glantz SA. Smoking in movies: a major problem and a real solution. Lancet 2003;362:258-9.

7. New York State Department of Health. New York State Department of Health urges Hollywood to take immediate action to rid movies our children see of smoking. New York State Department of Health, press release, 16 June 2008. http://www. nyhealth.gov/press/releases/2008/2008-06-

16 department urges action to rid movies of smoking.htm.

8. Rogers HC, Rogers C. No title, $\overline{2} 3$ Jan 1970. http://legacy.library.ucsf.edu/tid/ fyj90c00

9. Mekemson C, Glantz S. How the tobacco industry built its relationship with Hollywood. Tob Control 2002;11(Suppl 1):181-91.

10. St Romain T, Hawley SR, Ablah E, et al. Tobacco use in silent film: precedents of modern-day substance use portrayals. J Comm Health 2007;32:413-8.

11. Abbott S. Lights cigarette. Inhales lustily. Am Theater 1994:11:30

12. Sutton D. Current events in film: rituals of smoking in Hollywood's Golden Age: Hawks, Furthman and the ethnographic history of film. Film History 1999;29:70-85.

13. Higham C. North light and cigarette bulb. Sight Sound 1967:36:192.

14. Anonymous. Cigarette figures: a nine-year record of volume by brand; also advertising in newspapers, magazines and radio. Printers' Ink 1938;26 May.

15. Epstein EJ. The big picture: the new logic of money and power in Hollywood. New York: Random House, 2005

16. Horn NFN. The American Tobacco company. Fortune 1936:12

17. Barnouw E. The golden web; a history of broadcasting in the United States. Vol. 2, 1933 to 1953. New York: Oxford University Press, 1968.

18. Brocke W, Schlee EF, Thorp T, et al. No title, 13 May 1929. http://legacy.library. ucsf.edu/tid/izv70a00.

19. Curtis C, Pinza E, Raisa R, et al. Lucky Strike legal \& model releases, 22 Jan 1929 http://legacy.library.ucsf.edu/tid/hzv70a00

20. Corporate, Lucky Strike. Precious voice, 1927. http://legacy.library.ucsf.edu/tid/ ibe80a00

21. Corporate, Lucky Strike. Testimonial double \& group, testimonial package \& bull's eye, 1927. http://legacy.library.ucsf.edu/tid//be80a00.

22. Corporate, Lucky Strike. Cream of the crop, testimonials, male series, 1928. http://legacy.library.ucsf.edu/tid/kae80a00.

23. Bureau of Economics. Corporate appendixes A, B, and C for a report on cigarette advertising and output, 1964. http://legacy.library.ucsf.edu/tid/gji61e00.

24. Corporate, no title, 1931. http://legacy.library.ucsf.edu/tid/twd80a00.

25. Corporate, Lucky Strike. Frame series, movie stars, Bateman series, NY Times, Hayden, Lagatta, Christy, 1932. http://legacy.library.ucsf.edu/tid/qtw01a00.

26. Corporate, 'Cream of the Crop' Lucky Strike cigarettes 'the Extra Protection to My Throat' 'It's Toasted', 1932. http://legacy.library.ucsf.edu/tid/bga91f00.

27. Corporate, Lucky Strike. Precious voice campaign, 1937. http://legacy.library. ucsf.edu/tid/sae80a00

28. Corporate, Lucky Strike. Testimonial strip campaign, voice and tobacco expert campaign, 1937-38. http://legacy.library.ucsf.edu/tid/avd80a00.

29. Corporate, Lucky Strike. Newspaper advertising, Lucky Strike testimonial campaign, newspaper - legal releases, client's book 4, 16 Sep 1937. http://legacy. library.ucsf.edu/tid/gxu51a00

30. Brown \& Williamson. Corporate Brown \& Williamson, tobacco talk (vol. 2 no. 10), 1978. http://legacy.library.ucsf.edu/tid/pxe01c00.

31. Corporate, total Camel share of market by year. http://legacy.library.ucsf.edu/ tid/flz45a00.

32. Corporate, 1950-51. http://legacy.library.ucsf.edu/tid/rud80a00

33. Hahn PM. No title, 2 Mar 1949. http://legacy.library.ucsf.edu/tid/fwo51a00

34. Denove JBB. Rough Puff campaign, 6 Dec 1949. http://legacy.library.ucsf.edu/tid/ oef41a00.

35. Denove JBB. Rough Puff campaign, 13 Dec 1949. http://legacy.library.ucsf.edu/tid/ aef41a00

36. Batten B. No title, 22 Dec 1949. http://legacy.library.ucsf.edu/tid/kef41a00.

37. Corporate, release. Rough Puff campaign, Jan 1950. http://legacy.library.ucsf. edu/tid/def41a00.

38. RJ Reynolds. "Camels Agree with My Throat", 18 Dec 1950. http://legacy.library. ucsf.edu/tid/kxn89d00.
39. Corporate, phrases used in Lucky Strike advertising, 1955. http://legacy. library.ucsf.edu/tid/sdp35f00.

40. Corporate, Lucky Strike newspaper campaigns, 1966. http://legacy.library ucsf.edu/tid/xdp35f00.

41. Riggio-Lj ATC. Lucky Strike newspaper campaign, 2 Feb 1950. http://legacy.library ucsf.edu/tid/pzt85fo0.

42. Brandt AM. The cigarette century. New York: Basic Books, 2007.

43. National Better Business B. Advertising practices of the American Tobacco company, Sep 1930. http://legacy.library.ucsf.edu/tid/vlf39d00.

44. Ferguson GS Jr, Hill GW, Johnson OB. United States Of America before Federal Trade Commission, in the matter of American Tobacco company, a corporation, file no. 1-4989, stipulation as to the facts, 18 Nov 1929. http://legacy.library.ucsf.edu/ tid/whx70a00

45. Corporate, radio continuity, Lucky Strike, 1928-29. http://legacy.library.ucsf. edu/tid/nsw01a00

46. Time magazine. Warner Week. Time 1930;9 June.

47. Corporate, Lucky Strike testimonial campaign, book 2, 9 Dec 1937. http:// legacy.library.ucsf.edu/tid/jxu51a00.

48. Bickford C, Thomas GH, Boyd B, et al. No title, 15 Dec 1931. http://legacy.library. ucsf.edu/tid/lid15f00.

49. Bell R, Deaver F, Richards OV. No title, 13 Sep 1929. http://legacy.library.ucsf.edu/ tid/fzv70a00.

50. Segrave K. Endorsements in advertising. Jefferson, North Carolina: McFarland \& Company, 2005

51. Segrave K. Product placement in Hollywood films. Jefferson, North Carolina: McFarland \& Company, 2004.

52. Polzine P. Meeting Lucky Strike group, 14 Jan 1937. http://legacy.library.ucsf.edu/ tid/hes94f00

53. Welch J. Running record - Lucky Strike "Testimonial" campaign, 13 Jan 1937. http://legacy.library.ucsf.edu/tid/jes $94 f 00$.

54. McAvity TA. Lucky Strike testimonial campaign, 22 Jan 1937. http://legacy.library ucsf.edu/tid/fes94fo0.

55. McAvity TA. Lucky Strike testimonial campaign, 22 Jan 1937. http://legacy.library. ucsf.edu/tid/ees94f00.

56. McAvity TA. Lucky Strike testimonial campaign, 27 Jan 1937. http://legacy.library. ucsf.edu/tid/ces94f00.

57. Glover HB. Current status report on all names turned over to the writer for signing in the Lucky Strike endorsement campaign, 4 Feb 1937. http://legacy.library.ucsf. edu/tid/yds94f00

58. Corporate, no title, 1937. http://legacy.library.ucsf.edu/tid/ies94f00.

59. Runyon J, Marshall H. No title, 14 Dec 1937. http://legacy.library.ucsf.edu/tid/ wsd15f00.

60. Meredith B. No title, 19 Aug 1937. http://legacy.library.ucsf.edu/tid/lsf05f00.

61. Taves B. The B film: Hollywood's other half. In: Balio T, ed. Grand Design: Hollywood as a modern business enterprise, 1930-1939. Berkeley, California: University of California Press, 1993:313.

62. Corporate, Lucky Strike testimonial campaign, book 6, 1937. http://legacy. library.ucsf.edu/tid/oxu51a00.

63. Rogers JG Jr, Lewis C. Statement and release, 22 Jan 1937. http://legacy.library. ucsf.edu/tid/nil70a00.

64. General Screen Advertising. Motion picture advertising agreement, 16 Jul 1937. http://legacy.library.ucsf.edu/tid/izfo5fo0.

65. Corporate, this agreement, 9 Aug 1937. http://legacy.library.ucsf.edu/tid/ iyf05f00.

66. Anonymous. Raking films used by big advertisers; special reels being shown in theatres here as start of new exploitation program. Some cost \$25000 each. Producers adapt radio idea to the screen - public response said to be favorable. New York Times 13 January 1931; Sect Radio:30. http://select.nytimes.com/gst/ abstract.html?res = F40F1FF93E5E10728DDDAA0994D9405B818FF1D3\&scp $=$ $1 \& s q=$ paramount\&st $=p$

67. Tishman L, Reeve A. No title, 8 Sep 1931. http://legacy.library.ucsf.edu/tid/ jid15f00.

68. Silliman SE. No title, 21 Dec 1937. http://legacy.library.ucsf.edu/tid/usd15f00.

69. Lord \& Thomas. No title, 17 Jun 1938. http://legacy.library.ucsf.edu/tid/hrf05f00.

70. Corporate, agreement, 21 Jan 1973. http://legacy.library.ucsf.edu/tid/gsf05fo0.

71. Corporate, Lucky Strike testimonial campaign, book 7, 1937. http://legacy. library.ucsf.edu/tid/pxu51a00.

72. Hyde CL, Shore I. No title, 22 May 1939. http://legacy.library.ucsf.edu/tid/fij41a00.

73. Corporate, statement and release, agreement, 25 Jan 1937. http://legacy. library.ucsf.edu/tid/etd15f00

74. Silliman S, Raft G, Carter W, et al. Agreement George Raft, 08 Jun 1937. http:// legacy.library.ucsf.edu/tid/qtd15f00.

75. Sablon J, Schipa T, Shore D, et al. Statement and release Jean Sablon, 18 Feb 1938. http://legacy.library.ucsf.edu/tid/std15f00.

76. Corporate, Lucky Strike testimonial campaign, book 1, 9 Apr 1938. http:// legacy.library.ucsf.edu/tid//xu51a00.

77. Columbia Artists. No title, 30 Jan 1939. http://legacy.library.ucsf.edu/tid/ utd15f00.

78. Corporate, statement and releases as signed by "Tamara", 1937. http $/ /$ legacy.library.ucsf.edu/tid/wtd15f00.

79. Wain B, Weede R, Wettergren G, et al. No title, 20 0ct 1939. http://legacy.library ucsf edu/tid/fid15f00. 
80. Corporate, Lucky Strike, newspaper advertising, Lucky Strike testimonial campaign, legal releases - book 3, 12 Jun 1937. http://legacy.library.ucsf.edu/ tid/hxu51a00.

81. Raft G, Raymond G, Rayner S, et al. Statement - George Raft, 21 Jan 1937. http:// legacy.library.ucsf.edu/tid/otd15f00.

82. Bauer J0. No title, 11 Aug 1937. http://legacy.library.ucsf.edu/tid/tzf05f00.

83. Corporate, Lucky Strike testimonial campaign, book 1-A, 25 May 1937 http://legacy.library.ucsf.edu/tid/kxu51a00.

84. Corporate, Lucky Strike, newspaper advertising, legal releases, black \& white mag. Ads, American Tobacco company book, 1936. http://legacy.library. ucsf.edu/tid/byu51a00.

85. Miller C, No title, 10 Feb 1937. http://legacy.library.ucsf.edu/tid/wds94f00.

86. Transamerican Broadcasting \& Television Corporation. Amendment to agreement, 26 Nov 1937. http://legacy.library.ucsf.edu/tid/mro05f00.

87. Transamerican Broadcasting \& Television Corporation, Warner Bros Pictures, et al. No title, 10 Nov 1937. http://legacy.library.ucsf.edu/tid/qho05f00.

88. Corporate, repetition is reputation, 1943. http://legacy.library.ucsf.edu/tid/ chs70a00.

89. Corporate, no title, 10 Apr 1944. http://legacy.library.ucsf.edu/tid/xgk75f00.

90. FTC Office Of Information. No title, 5 Apr 1950. http://legacy.library.ucsf.edu/tid/ hgo15f00.

91. Corporate, radio continuity, Lucky Strike, Jack Benny, Jan-Mar 1947, Jan 1947. http://legacy.library.ucsf.edu/tid/zid80a00.

92. Anonymous. Cigarette ads cited in complaint by FTC; Pall Mall and Lucky Strike are asked to revise claims. New York Times 1 September 1942; Sect business, financial:33. http://select.nytimes.com/gst/abstract.html?res = FB0811FC3D581B7B93C3A91782 D85F468485F9\&scp $=2 \& s q=$ advertising \&st $=p$

93. Anonymous. Cigarette testimonial signers - and how they get that way. Printers' Ink 1944, 14 April:17.
94. Anonymous. FTC cracks down on cigarette ads; Camels, Old Golds are named but Commission says many abuses have been ended. Testimonials are scored: some endorsers non-smokers, others couldn't read - charges called unfair. New York Times 6 April 1950;Sect special:30. http://select.nytimes.com/gst/abstract. $\mathrm{html}$ ?res = F5081FFA385F177A93C4A9178FD85F448585F9\&scp $=2 \& s q=$ advertising $\& s t=p$.

95. Anonymous. Leading advertisers of 1946 and their expenditures. Printers' Ink 1947 18 April:47.

96. Quigley Publishing Company. Top ten money making star of the past 76 years 2007. http://www.quigleypublishing.com/MPalmanac/Top10/Top10_lists.html (accessed 29 February 2008)

97. Anonymous. 203,000 cigarettes used each minute. New York Times 25 Novembe 1928; Sect editorial:7. http://select.nytimes.com/gst/abstract.html?res = F60913FE3E5A127A93C7AB178AD95F4C8285F9\&scp $=1 \& s q=$ cigarettegst $=p$.

98. Anonymous. Cigarette producers seeking sales of 400 billion annually...'Untapped market,' women of Mid-West, pivotal in plans. New York Times 11 March 1946; Sect business \& finance: 32 .

99. Time magazine. Tobacco. Time 1930:17 March.

100. Thomson D. A system gone with the wind. Los Angeles Times 21 May 2006 http://www.latimes.com/entertainment/news/cl-ca125thomson21may21,0,1186813.story.

101. Fleming E. The fixers. Jefferson, North Carolina: McFarland \& Company, 2004

102. Glantz SA, Kacirk K, McCullough C. Back to the future: smoking in the movies in 2002 compared with 1950 levels. Am J Pub Health 2004;94:261-2.

103. Corporate, Lucky Strike, first \& second sweets series, 1928-1929, 1928. http://legacy.library.ucsf.edu/tid/lae80a00.

104. Corporate, Lucky Strike, four color, black \& white, 1927-29, 1927. http:// legacy.library.ucsf.edu/tid/hbe80a00.

\section{BMJ Careers online re-launches}

BMJ Careers online has re-launched to give you an even better online experience. You'll still find our online services such as jobs, courses and careers advice, but now they're even easier to navigate and quicker to find.

New features include:

- Job alerts - you tell us how often you want to hear from us with either daily or weekly alerts

- Refined keyword searching making it easier to find exactly what you want

- Contextual display - when you search for articles or courses we'll automatically display job adverts relevant to your search

- Recruiter logos linked directly to their organisation homepage - find out more about the company before you apply

- RSS feeds now even easier to set up

Visit careers.bmj.com to find out more. 